\title{
The role of green supply chain management practices on environmental performance in the hydrocarbon industry of Bahrain: Testing the moderation of green innovation
}

\author{
Saad Darwish $^{a^{*}}$, Syed Mir Muhammad Shah ${ }^{\mathrm{b}}$ and Umair Ahmed
}

${ }^{a}$ Kingdom University, Bahrain

${ }^{b}$ Sukkur IBA University, Sukkur, Sindh Pakistani, Pakistan

cArab Open University, Bahrain

\begin{tabular}{|c|c|}
\hline CHRON I C L E & A B S T R A C T \\
\hline $\begin{array}{l}\text { Article history: } \\
\text { Received November 6, } 2020 \\
\text { Received in revised format } \\
\text { January, 25, 2021 } \\
\text { Accepted March } 82021 \\
\text { Available online } \\
\text { March } 82021 \\
\text { Keywords: } \\
\text { Green supply chain } \\
\text { Green purchase } \\
\text { Internal environmental } \\
\text { management } \\
\text { Customer environmental } \\
\text { cooperation } \\
\text { Environment performance } \\
\text { Green innovation }\end{array}$ & $\begin{array}{l}\text { Recently, environmental degradation has become a global issue, and a green supply chain has } \\
\text { been considered as the appropriate solution for it. Also, this issue gets the intentions of recent } \\
\text { researchers. Thus, the current article aims to examine the impact of green supply chain practices } \\
\text { such as green purchase, internal environmental management, and customer environmental } \\
\text { cooperation on environment performance in Bahrain. The goal also includes examining the } \\
\text { moderating role of green innovation among the nexus of green purchase, internal environmental } \\
\text { management, customer environmental cooperation, and environmental performance in Bahrain. } \\
\text { The primary data collection method has been executed by the study and collected data by using } \\
\text { questionnaires. The employees of the supply chain department of the hydrocarbon industry in } \\
\text { Bahrain are the respondents. The statistical results show that green purchase, internal } \\
\text { environmental management and customer environmental cooperation have positive relationships } \\
\text { with environmental performance. The outcomes also exposed that green innovation has played } \\
\text { an influential moderating role among the nexus of green purchase, internal environmental } \\
\text { management, customer environmental cooperation, and environmental performance in Bahrain. } \\
\text { These findings provide guidelines to the regulators that they should develop effective policies } \\
\text { related to the implementation of supply chain practices that improve environmental performance. }\end{array}$ \\
\hline
\end{tabular}

(C) 2021 by the authors; license Growing Science, Canada.

\section{Introduction}

It is quite evident that there is an increasing concern about the impacts of industrial enterprises on the natural environment and health of the general people as the industries are involved in the activities, processes, and utilization of such technologies that create pollution in the natural environment. Hence, there is an emerging requirement to apply such practices as they may meet the economic, social, and environmental necessities at a time. Therefore, industrial enterprises are under intense pressure from the emerging competitive market, government regulators, and society to create and maintain a balance among economic, social, and environmental performance (Diabat \& Govindan, 2011; Casas-Rosal et al., 2019; Afonso \& Silva, 2019; Sarkın \& Gülleroğlu, 2019; Tekir \& Akar, 2019). As per the past investigation, the industrial enterprises that have succeeded in maintaining such balance take an active part in markets and have competitive advantages over their market rivals. Undeniably, It seems to be difficult but a challenge to maintain such balance among the economic, social, and environmental performance. The difficulty rises when companies work on implementing environmental management systems efficiently to improve social and environmental performance and meet the purpose of better economic performance. To overcome such a difficulty, companies should introduce some changes in the policies, strategies, manufacturing, operational, and marketing processes, which bring a better social and environmental performance without disturbing the goals of higher economic performance (Sarkis, Zhu, \& Lai, 2011; Polat, Guncavdi \& Arslan, 2019; Ozgen, 2019). Besides,

* Corresponding author

E-mail address: saad.darwish@ku.edu.bh (S. Darwish)

C 2021 by the authors; licensee Growing Science. doi: $10.5267 /$ j.uscm.2021.3.006 
the application of green supply chain management practices is beneficial to enterprises as it enables them to satisfy government regulators, the general public, and society about their environmental concerns and meet the economic requirement. The current study aims to examine three significant green supply chain management practices that contribute towards environmental performance. Such green practices include internal environmental performance, green purchasing, and customer environmental cooperation. The efficient internal environmental management in a specific chain node brings improved environmental performance because it monitors and handles environmental issues of manufacturing, operational, and marketing undertakings (Tseng, Islam, Karia, Fauzi, \& Afrin, 2019; Muposhi, 2019; Mokoena, 2019; ). Similarly, green purchasing is one of the significant practices of the green supply chain, which helps to avoid the harmful impacts of raw material and other resources. Moreover, the customer environmental cooperation also helps the enterprises to keep a check on the negative impacts of their activities and machinery on society and the environment (Ninlawan, Seksan, Tossapol, \& Pilada, 2010; Auriacombe \& Vyas-Doorgapersad, 2019; Mothibi \& Mncayi, 2019; Athiyaman \& Magapa, 2019; Moolman \& Jacobs, 2019).

The purpose of the current study is to analyze the contribution of green supply chain management practices like internal environmental management, green purchasing, and customer environmental cooperation to the environmental performance of the hydrocarbon industry of Bahrain. The in-depth investigation has proved that the hydrocarbon industry, which consists of petroleum, oil, and gas enterprises has a potential part in the economy of Bahrain but in other words, it can be said that the economy of Bahrain is dependent on the enterprises engaged in petroleum, oil, and gas (Farahat, 2016). Petroleum production is its most exported product. Its share in exports is $60 \%$ in export revenues, $70 \%$ in government revenues, and $11 \%$ in GDP. As per long term analysis by Soofi and Pai (2018), Bahrain extracts oil and gas and imports crude forms of oil and gas as well and further refines them to make them able to be utilized by end consumers. In this regard, different procedures and heavy machinery and plants are applied, which are likely to create several environmental problems. The hydrocarbon industry produces land, air, and water pollution by emitting harmful gases, toxic substances, and flowing chemicals in open water sources. As the survival and growth of Bahrain's economy are mostly dependent on the hydrocarbon industry, it utilizes most of the portion of its land for extraction and refining of oil and gas, which damages its land and spoils its fertility (Nakibullah, 2018). Considering the negative environmental impacts of enterprises engaged in the hydrocarbon industry, the Bahrain government is taking steps to introduce green supply chain management practices to satisfy the environmental concerns of society and regulators (Khayati \& Al-Sayegh, 2020). This environmental compassion is emerging in the hydrocarbon industry in Bahrain, which helps to overcome the industry's negative impacts on the natural environment and health of the general public. Thus, enterprises in the hydrocarbon industry of Bahrain that are implementing and executing green supply chain management practices are making rapid progress in showing environmental performance and achieving higher economic performance (Louër, 2013; Isabirye \& Moloi, 2019; Mokoena \& Dhurup, 2019; Bonal et al., 2019; Galatti et al., 2019; ). While the industries which are still lacking in implementing green practices like internal environmental management, green purchasing, and customer environmental cooperation. This, as a result, is worsening the natural environment, society, and health of the general public.

Internal environmental management, green purchasing and customer environmental cooperation are the three main dimensions of green supply chain management that help organizations within the supply chain achieve superior environmental performance. The effectively implemented practices of internal environmental management contribute enormously to the environmental performance of enterprises (Green, Zelbst, Meacham, \& Bhadauria, 2012; Chetthamrongchai et al., 2019; Hadi, 2019; ). Besides this, the effective internal environmental management of individual firms within the chain determines the environmental performance across the chain as it makes it possible to integrate ecofriendly knowledge and information, eco-friendly resources, techniques, and procedures throughout the chain. Similarly, green purchasing also known as environmentally preferable purchasing, is the procurement of material, resources, and services that have lessor negative impacts on the environment than at the different stages of their lifecycle $(\mathrm{Ji}, \mathrm{Ma}, \& \mathrm{Li}$, 2015; Nataraj et al., 2019; Papanas et al., 2019). Likewise, customer environmental cooperation creates environmental awareness and helps carry out successful environmental programs that improve environmental performance. The study implies that green innovation is a considerable moderator between green supply chain practices and environmental performance. Green innovation is the use of different kinds of innovative hardware and software which affect the products, resources, and processes in term of environmental aspects; thus, products, organizational resources, operational and marketing procedures do not put harmful impacts on the natural environment and the health of the general public (Weng, Chen, \& Chen, 2015). The current study examines green innovation, which affects green supply chain practices like internal environmental management, green purchasing, customer environmental cooperation, and environmental performance, and strengthens their mutual association.

The study elaborates the effects of three dimensions of green supply chain management like internal environmental management, green purchasing, customer environmental cooperation and environmental performance, and an appropriate moderator of green innovation in the hydrocarbon industry in Bahrain with the help of a theoretical framework and methodology. Lastly, the paper offers discussion, implications, and conclusion.

\section{Research Objectives and Significance of the Study}

The current study aims to examine the three significant variables of green supply chain management practices -, green purchasing, internal environmental performance and customer environmental cooperation- that contribute to the 
enhancement of environmental performance. Furthermore, to analyze environmental support to the environmental performance of the hydrocarbon industry of Bahrain and reproduce some recommendations for decision-makers to help the economy. An appropriate moderator of green innovation in the hydrocarbon industry in Bahrain with the help of a theoretical framework and methodology. Lastly, the paper offers discussion, implications, and conclusion. The study elaborates on the effects of three dimensions of green supply chain management mentioned here.

\section{Literature Review}

The main goal of any business enterprise is to strengthen their position in the market among their rivals and to earn more profits. However, this primary goal is difficult to achieve while ignoring social and environmental requirements. Enterprises can improve the profitability rate only when they care for the general public, society, and natural environment are considered. For the customers prefer to deal with those enterprises which do not prove to be harmful to the natural resources of the country and their health (Ninlawan et al., 2010). That is why business enterprises' primary goal to have more and more profitability is impossible to achieve without achieving superior environmental performance. The tendency of industrial enterprises towards superior environmental performance has been at the center of interest for researchers and scholars. The long term analysis and debate by scholars like Laosirihongthong, Adebanjo, and Tan (2013) have proved that green supply chain practices play a significant role in boosting environmental performance. Green supply chain management refers to integrating business thinking to remove negative environmental impacts from the typical supply chain management.

Moreover, the green supply chain management performs practices like environmental friendly product designing, sourcing of material, selecting goods, manufacturing methods, selling, and eco-friendly delivery of finished goods to end consumers. Accordingly, green supply chain management also takes care of environmental issues throughout the life cycle of the products, and once they are disposed or discarded (Sarkis, 2012). In Bahrain, the enterprises in the hydrocarbon industry, which are connected in the supply chain, are tending to improve environmental performance for achieving economic goals by implementing and executing green supply chain practices efficiently. Still, some enterprises in Bahrain's hydrocarbon industry are integrated within the supply chain, but do not benefit from practices of green supply chain management, which adversely affects their environmental performance and their economic progress. The internal environmental management within particular chain nodes helps the supply chain management to fulfill the environmental demands of the general public, customers, and government regulators (Paillé, Chen, Boiral, \& Jin, 2014).

Similarly, the procurement of green material and other resources helps industrial enterprises to minimize adverse environmental effects. Besides, customer environmental cooperation proves to be beneficial in this respect as it enables the business management to keep an eye on customers' environmental requirements. Thus, general public can reshape their activities, procedures, and manufacturing to meet those requirements. Green innovation plays a significant moderating role between the practices of the green supply chain, such as internal environmental management, green purchasing, and customer environmental cooperation and the achievement of environmental performance.

\subsection{Internal Environmental Management and Environmental Performance}

There are several green supply chain management practices whose main purpose is to minimize or remove the negative impacts of the business activities of the enterprises towards the society, natural resources, and atmosphere of the environment and thereby remove negative environmental impacts from human health. The superior environmental performance, attained with the implementation and execution of green supply chain practices, improves the overall performance of chain partner firms and determines superior economic growth (López-Gamero \& Molina-Azorín, 2016). Internal environmental management is composed of elements within the organization, including current employees, management, and especially corporate culture, which defines employee behavior. Although some elements affect the organization as a whole, others affect only the manager.

The green supply chain dimensions that help the individual partner firms within the chain to remove the adverse ecological effects of organizational resources, technology, operations, and production procedures. One of the objectives of internal environmental management is to implement policies for acquiring environmentally friendly material and resources and utilize them taking the environmental aspects under consideration. Under internal environmental management, eco-friendly technology and machinery are used, producing minimum toxic and waste substances.

Moreover, the operational procedures and production methods are kept eco-friendly, which do not emit contaminating and toxic material, water, gases, and other substances (Marelli, 2015). In addition, for advertisement, eco-friendly material and channels and logistics are used, safe marketing procedures are applied, and for the acquisition of raw material and the delivery of finished goods, eco-friendly logistics are used. Besides, internal environmental management decides for the periodical training of the human resources of the organizations to undertake their functions in such a way as to minimize the wastes and the emission of contaminating and toxic substances. That is how internal environmental management determines higher environmental performance (Piltan, Mansoorzadeh, Akbari, Zare, \& ShahryarZadeh, 2013). The effective 
and efficient internal environmental management in the individual chain nodes in the hydrocarbon industry in Bahrain leads to particular chain nodes' environmental performance and overall chain's environmental performance.

$\mathbf{H}_{1}$ : Internal environmental management has a positive relationship with environmental performance.

\subsection{Green Purchasing and Environmental Performance}

Green purchasing, in other words, environmentally preferable procurement, is one of the significant dimensions of green supply chain management, which leads to great improvement in environmental performance (González-Benito, Lannelongue, Ferreira, \& Gonzalez-Zapatero, 2016). Within a supply chain, the policies, undertakings, and procedures of a particular business firm affect all the firms' policies, strategies, and procedures within the chain, positively or negatively. That is why the purchasing of raw material, resources, and services which are likely to reduce negative effects on the natural environment while compared with others at several stages such as acquiring material, production, packing, delivery, marketing, operation, usage and disposal, enables the organizations to requirements of the general public, customers, and government regulators about environmental concerns (Dubey, Gunasekaran, \& Ali, 2015). The quality and characteristics of all resources, materials, and services constitute the degree of industrial organizations' environmental performance. If the quality of raw material is good, and they do not have toxic substances, they will not negatively impact the health of the general public and customers. Similarly, when skilled, educated, talented, and trained workers are hired, these people struggle to give ecological results by reducing the chances of waste material and removing the creation of toxic material. Likewise, higher quality resources like transportation and different technology types help improve environmental performance (Large \& Thomsen, 2011).

\section{$\mathbf{H}_{2}$ : Green purchasing is in a positive relationship with environmental performance.}

\subsection{Customer Environmental Cooperation and Environmental Performance}

In the emerging business environment, the relationships of business organizations with their customers are of great importance for social, economic, and environmental performance. In the case of the company's struggle to achieve superior environmental performance, the cooperation from customers and its importance cannot be denied. The investigation by Theyel (2006) states that customer relationship management (CRM) is established, which manages to interact with the past as well as existing and potential customers to meet the organizational goals. The customers' cooperation in environmental programs proves to be healthful in environmental programs as they help the organization to keep its environmental activities up-dated. According to Walls, Berrone, and Phan (2012), the customer views and observations about environmental aspects help the industrial organizations to launch environmental programs. Moreover, if the customers cooperate with the industrial organizations, they can change products features and characteristics of advertisement material according to environmental requirements. Besides, customers may cooperate with industrial enterprises in the proper disposal of products and services and they may also cooperate with enterprises in launching eco-friendly marketing channels which do not harm natural resources of the country and the health of the general public; thus the cooperation from customers help in meeting the environmental requirements of the general public, customers, and government regulators (Large \& Thomsen, 2011). In Bahrain, where the hydrocarbon industry occupies a larger place in the economy, customer environmental cooperation, one of the significant green supply chain practices, plays a key role in minimizing the environmental impacts of enterprises involved in the hydrocarbon industry. While some enterprises in the hydrocarbon industry in Bahrain lack in customer environmental cooperation and have a relatively smaller portion in environmental performance.

\section{H3: Customer environmental cooperation has a positive association with environmental performance.}

\subsection{Green Innovation and Environmental Performance}

The scholar Carrión-Flores and Innes (2010) is of the view that green innovation is the innovation in technologies which are expected to save energy, prevent pollution, help in recycling of wastes, to apply eco-friendly product designs, and makes sure the proper disposal of goods and services after the useful life. The green innovation enables the industrial organizations to show superior performance by meeting all the requirements of the general public, customers, government regulators about environmental issues. Furthermore, the innovation in the technology used for production helps reduce the toxic creation products, emission of hazardous material and chemicals, and the emission of contaminating gases, thus assisting in achieving superior environmental performance (Qi, Shen, Zeng, \& Jorge, 2010). Similarly, the environmental innovation in logistics reduces air pollution by minimizing the chances of emission of contaminating gases and toxic smoke. In Bahrain, in the enterprises involved in the hydrocarbon industry, the green innovation brought in the plants, technologies, logistics, and the procedures of extraction, processing, and refining crude oil, petroleum, and gases reduce the polluting effects of industry on the environment and thus raises the scale of environmental performance (Darwish et al., 2009).

\section{Green Innovation as Moderator between Green Supply Chain Management Practices and Environmental Performance}

Innovation has started attracting accelerated research over the recent years (Phankhong et al., 2020). The creation of green innovation in the technology, logistics, and procedures (operational, production, advertisement, and marketing procedures) ensures the effective implementation and execution of different practices of green supply chain management whose basic purpose is to bring improvement in the environmental performance of individual chain nodes and the overall environmental 
performance of supply chain. The introduction of green innovation in the industry ensures the implementation of three significant green supply chain practices like internal environmental management, green purchasing, and customer environmental cooperation, which further helps in improving environmental performance (Cuerva, Triguero-Cano, \& Córcoles, 2014). In this way, green innovation strengthens the relationship between green management practices like internal environmental management, green purchasing, and customer environmental cooperation and environmental performance. Internal environmental management works more effectively when there is a tendency to bring green innovation within the organizations. Then the internal environmental management is in a better position to improve environmental performance (Darwish et al., 2018).

Similarly, green innovation motivates organizational management to make environmentally preferable purchasing, minimizing pollution creation, and improving environmental performance. Besides, green innovation motivates the green supply chain management to establish attraction with the customers to have environmental cooperation from them which improve environmental awareness and can be beneficial in undertaking eco-friendly activities to enjoy the superior environmental performance (Schiederig, Tietze, \& Herstatt, 2012). The following hypothesis is made based on the above discussion:

H4: Green innovation is an appropriate moderator between internal environmental management and environmental performance.

H5: Green innovation is a considerable moderator between green purchasing and environmental performance.

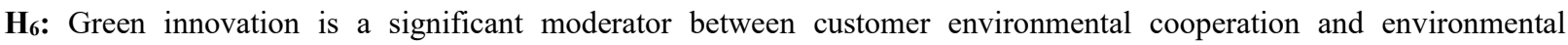
performance.

\section{Research Problem}

We have evidence that there is a need for adopting Strategic Environmental Assessment (SEA). There should be a cooperation between major companies in the field of oil, petrochemical, and gas industries (Mustafa, .et al 2019). This need has its impact on environmental performance in the hydrocarbon industry in Bahrain. Therefore, this research will concentrate of the green supply chain and to investigate how this will enhance the environment and creates support for a green supply chain that will enhance Bahrain environmental index in the long run.

\subsection{Operationalization of the Constructs}

Green purchasing refers to the application of environmentally friendly procedures to purchase pro-environment raw material and supplies (Min \& Galle, 1997). Accordingly, we operationalize internal environmental management refers to the internal management of organizational practices related to supply chain with pro-environmental focus (Piltan et al., 2013). Likewise, customer cooperation in environmental programs refers activities facilitating customer environmental assistance to promote environmental activities in the supply chain (Large \& Thomsen, 2011). Furthermore, the present study operationalizes green innovation following the assertinos of Carrión-Flores and Innes (2010) as activities bringing innovative developments in the core supply chain activities for pro-environmental contribution.

\subsection{Research Methods}

The purpose of the research is to examine the impact of green purchase, internal environmental management and customer environmental cooperation on environmental performance and the examination of the moderating role of green innovation among the nexus of green purchase, internal environmental management, and customer environmental cooperation and environment performance in Bahrain. A surge in research has been reported in the recent on Bahrain which is an encouraging sige (e.g., Ogalo, 2020; Ahmed, 2019). The primary data collection method has been executed by the study and collected data by using questionnaires. The respondents have been selected on the basis of simple random sampling. The employees of the supply chain department of the hydrocarbon industry in Bahrain are the respondents. A total of 540 questionnaires have been sent to them by mail and personal visit. After one month of distribution, only 290 surveys were returned, representing approximately 53.70 percent of the response rate. In addition, an effective tool of data analysis named smartPLS has been used by the researchers to check the reliability, validity, and hypotheses testing due to the complex model has been adopted by the study (Sarstedt \& Cheah, 2019). The constructs that have been adopted by the research include three practices of the green supply chain, including a six-item scale for internal environmental management (IEM); a nine-item scale for green purchase (GP) and a seven-item scale for customer environmental cooperation (CEC) (Eltayeb \& Zailani, 2014). In addition, green innovation (GI) has been used as a moderating variable and has eight items (Bernauer, Engel, Kammerer, \& Sejas Nogareda, 2007) while environmental performance has been used as the predictive variable that has sixteen items (Seman et al., 2019). These constructs, along with relationships, have been highlighted in Fig. 1.

\section{Findings}

The outcomes section of the study includes the measurement model assessment along with the structural model assessment. The measurement model assessment includes verifying convergent and discriminant validity, while the structural model assessment includes hypotheses testing. Firstly, the current study shows the measurement model assessment by using 
convergent validity that is about the correlation among items. The figures highlighted that composite reliability (CR) and Alpha values are higher than 0.70, while AVE and loadings are bigger than 0.50 . These are the pieces of evidence of extensive correlation among items and valid convergent validity. These values are mentioned in Table 1.

\section{Green Supply Chain Practices}

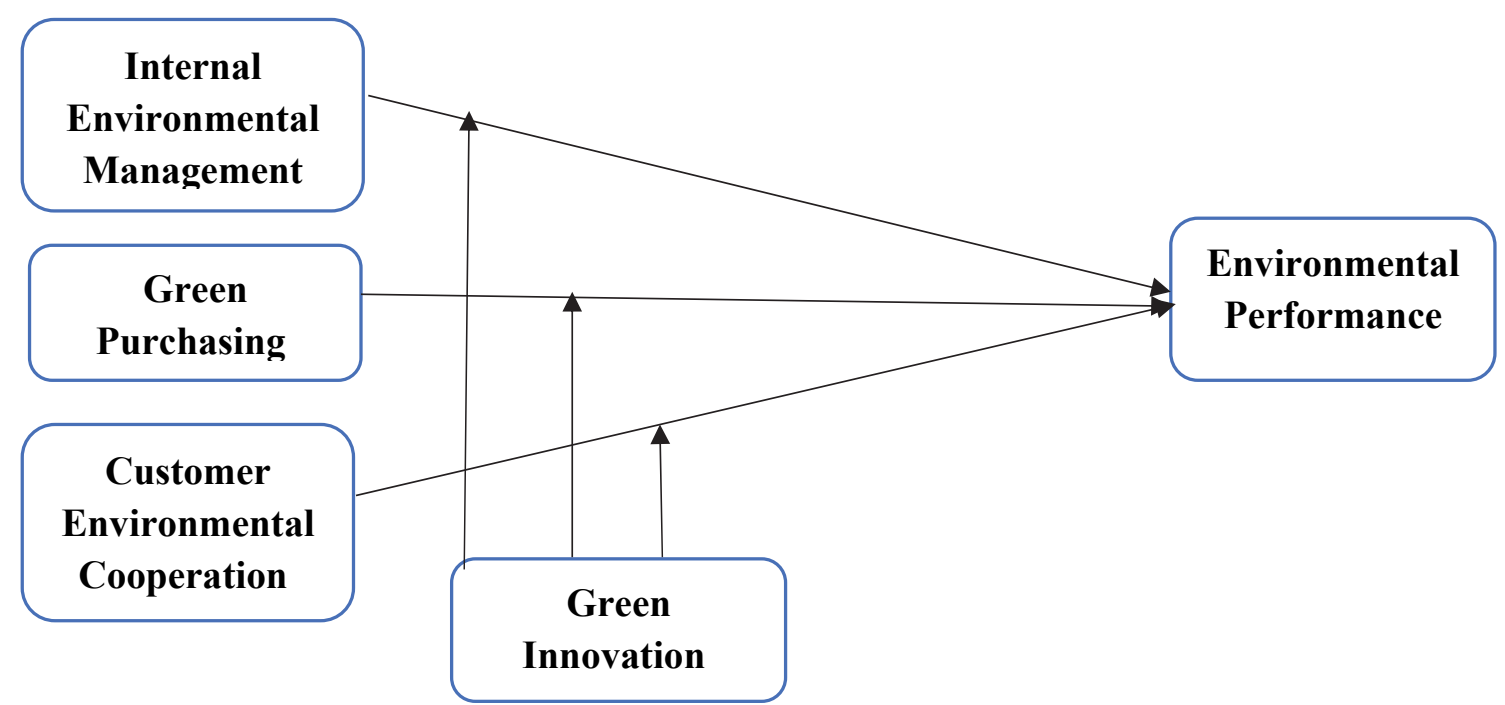

Fig. 1. Theoretical Framework

Table 1

Convergent validity

\begin{tabular}{|c|c|c|c|c|c|}
\hline Constructs & Items & Loadings & Alpha & $\mathbf{C R}$ & AVE \\
\hline \multirow[t]{7}{*}{ Customer Environmental Cooperation } & CEC1 & 0.864 & \multirow[t]{7}{*}{0.934} & \multirow[t]{7}{*}{0.947} & \multirow[t]{7}{*}{0.717} \\
\hline & $\mathrm{CEC} 2$ & 0.846 & & & \\
\hline & CEC3 & 0.827 & & & \\
\hline & CEC4 & 0.865 & & & \\
\hline & CEC5 & 0.875 & & & \\
\hline & CEC6 & 0.859 & & & \\
\hline & $\mathrm{CEC7}$ & 0.788 & & & \\
\hline \multirow[t]{10}{*}{ Environmental Performance } & EP1 & 0.576 & \multirow[t]{10}{*}{0.920} & \multirow[t]{10}{*}{0.934} & \multirow[t]{10}{*}{0.588} \\
\hline & EP10 & 0.783 & & & \\
\hline & EP13 & 0.814 & & & \\
\hline & EP14 & 0.843 & & & \\
\hline & EP2 & 0.801 & & & \\
\hline & EP4 & 0.786 & & & \\
\hline & EP5 & 0.767 & & & \\
\hline & EP6 & 0.648 & & & \\
\hline & EP8 & 0.812 & & & \\
\hline & EP9 & 0.797 & & & \\
\hline \multirow[t]{8}{*}{ Green Innovation } & GI1 & 0.657 & \multirow[t]{8}{*}{0.912} & \multirow[t]{8}{*}{0.918} & \multirow[t]{8}{*}{0.584} \\
\hline & GI2 & 0.772 & & & \\
\hline & GI3 & 0.802 & & & \\
\hline & GI4 & 0.798 & & & \\
\hline & GI5 & 0.809 & & & \\
\hline & GI6 & 0.787 & & & \\
\hline & GI7 & 0.782 & & & \\
\hline & GI8 & 0.690 & & & \\
\hline \multirow[t]{9}{*}{ Green Purchase } & GP1 & 0.893 & \multirow[t]{9}{*}{0.948} & \multirow[t]{9}{*}{0.956} & \multirow[t]{9}{*}{0.708} \\
\hline & GP2 & 0.893 & & & \\
\hline & GP3 & 0.842 & & & \\
\hline & GP4 & 0.870 & & & \\
\hline & GP5 & 0.863 & & & \\
\hline & GP6 & 0.727 & & & \\
\hline & GP7 & 0.868 & & & \\
\hline & GP8 & 0.863 & & & \\
\hline & GP9 & 0.733 & & & \\
\hline \multirow[t]{5}{*}{ Internal Environmental Management } & IEM1 & 0.953 & \multirow[t]{5}{*}{0.964} & \multirow[t]{5}{*}{0.972} & \multirow[t]{5}{*}{0.874} \\
\hline & IEM2 & 0.935 & & & \\
\hline & IEM4 & 0.944 & & & \\
\hline & IEM5 & 0.954 & & & \\
\hline & IEM6 & 0.887 & & & \\
\hline
\end{tabular}


Secondly, the current study also shows the measurement model assessment by using discriminant validity that is about the correlation among variables. The figures highlighted that the Heterotrait Monotrait (HTMT) ratios are not more than 0.90. These are the shreds of evidence of lack of correlation among variables and valid discriminant validity. These values are mentioned in Table 2.

Table 2

Discriminant validity

\begin{tabular}{llllll}
\hline & CEC & EP & GI & GP & IEM \\
\hline CEC & & & & \\
EP & 0.445 & & & \\
GI & 0.259 & 0.266 & & \\
GP & 0.464 & 0.552 & 0.243 & \\
IEM & 0.452 & 0.495 & 0.484 & 0.512 \\
\hline
\end{tabular}

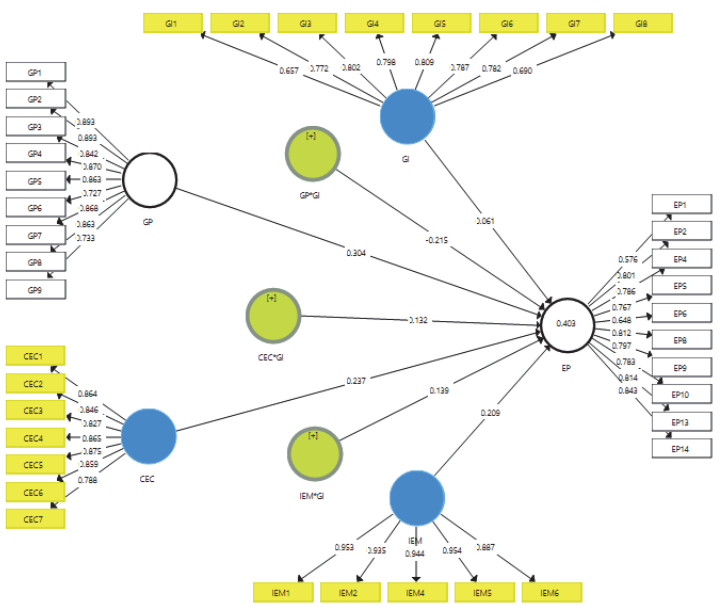

Fig. 2. Measurement model assessment

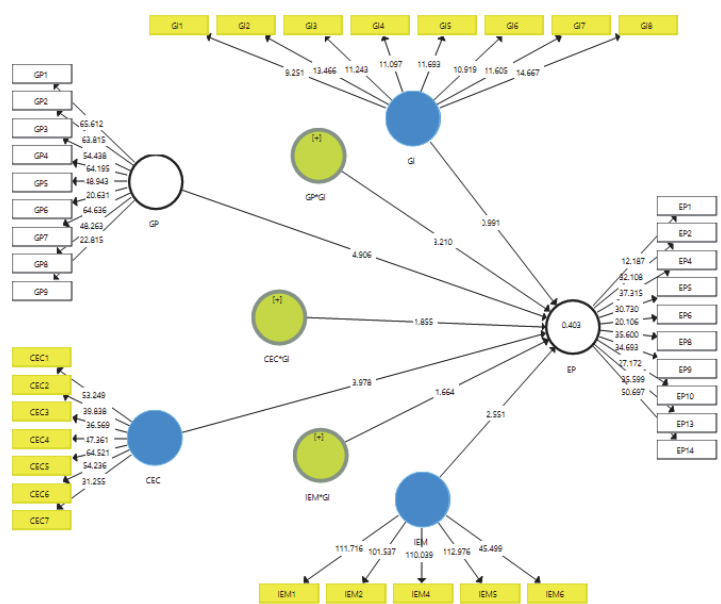

Fig. 3. Structural model assessment

Finally, the structural model assessment has been executed by using path analysis, and the results show that green purchase, internal environmental management, and customer environmental cooperation have positive relationships with environmental performance in Bahrain and accept H1, H2, and H3. In addition, the outcomes also exposed that green innovation has played an effective moderating role among the nexus of green purchase, internal environmental management, customer environmental cooperation, and environment performance in Bahrain and accept H4, H5 and H6. These values are mentioned in Table 3 and Fig. 3.

Table 3

Path analysis

\begin{tabular}{lccccc}
\hline Relationships & Beta & S.D. & t-statistics & p-values & L.L. \\
\hline $\mathrm{CEC} \rightarrow$ EP & 0.237 & 0.060 & 3.978 & 0.000 & 0.140 \\
$\mathrm{CEC} \times$ GI $\rightarrow$ EP & 0.132 & 0.071 & 1.855 & 0.033 & 0.009 \\
$\mathrm{GP} \rightarrow$ EP & 0.304 & 0.062 & 4.906 & 0.000 & 0.196 \\
$\mathrm{GP} * \mathrm{GI} \rightarrow$ EP & 0.215 & 0.067 & 3.210 & 0.001 & 0.337 \\
$\mathrm{IEM} \rightarrow$ EP & 0.209 & 0.082 & 2.551 & 0.411 & 0.117 \\
$\mathrm{IEM} * \mathrm{GI} \rightarrow$ EP & 0.139 & 0.083 & 1.664 & 0.06 & 0.050 \\
\hline
\end{tabular}

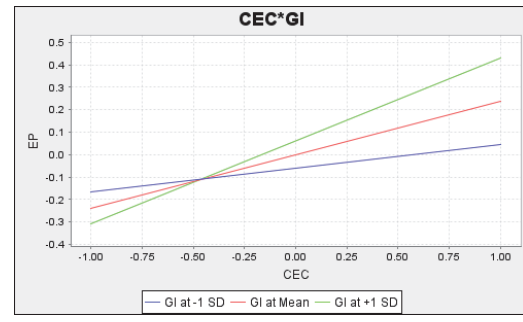

Fig. 4. $\mathrm{CEC} \times \mathrm{GI}$

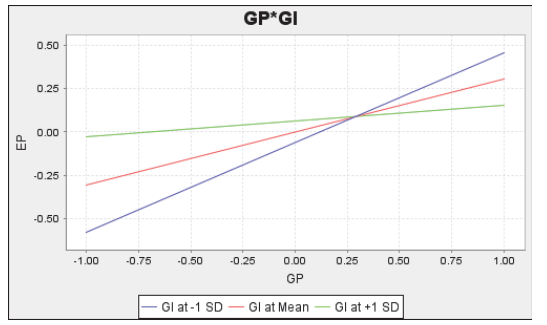

Fig. 5. GP $\times$ GI

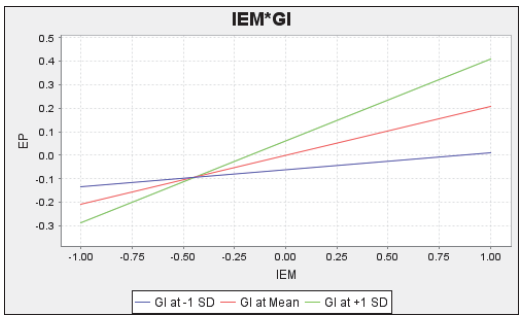

Fig. 6. IEM $\times$ GI 


\section{Discussion and Implications}

The results of the study have revealed that internal environmental management has a positive association with environmental performance. These results are in line with the previous studies of Zeng et al. (2011), which reveal that if internal environmental management practices are implemented and executed efficiently, it is likely for the business enterprises to show higher environmental performance. These results are also in line with past studies of Yang, Hong, and Modi (2011), which prove the significance of internal environmental management, one of the green supply chain practices, in the attainment of superior environmental performance. The results have indicated that green purchasing is in a positive relationship with the degree of environmental performance. These results are supported by past studies of Yen and Yen (2012) which show the great contribution of green supply chain practice, green purchasing to environmental performance. The studies also approve these results of Lin (2013), which prove that green purchasing the industrial enterprises within the supply chain can show better environmental performance. Moreover, the study results have indicated that customer environmental cooperation puts positive influences on environmental performance. These results agree with the results of past studies of Laari, Töyli, Solakivi, and Ojala (2016), according to which the customer environmental cooperation plays a key role in the fulfillment of customers' environmental requirements, the general public, and government regulators. These results also match with the past studies of Zhu, Geng, and Lai (2010), which prove that the cooperation with the customers in case of environmental aspects enables the organizations to understand the environmental requirements of general people customers and make their environmental procedures more effective. The study results have represented that green innovation plays a moderating role between green supply chain practices like internal environmental management and environmental performance. These results are in line with the past studies of Li (2014), which shed light on the point that green innovation improves internal environmental management efficiency and thereby improves the rate of environmental performance. The results have indicated that green innovation is a significant moderator between green purchasing and environmental performance. These results match with the studies of Epstein, Buhovac, and Yuthas (2015), which prove that green innovation affects green purchasing, and environmental performance and make their mutual association stronger. Furthermore, the results have exposed that green innovation is an appropriate moderator between green supply chain practice, customer environmental cooperation, and environmental performance. These results are in line with previous studies (Chiou, Chan, Lettice, and Chung (2011)) which imply that green innovation improves the relationship between customer environmental cooperation and environmental performance.

The current study makes both theoretical implications and empirical implications. From the theoretical perspective, it can be said that the study contributes a lot to the literature on business management. The study sheds light on the crucial role of green supply chain management practices in achieving higher environmental performance. It introduces three significant green supply chain management practices, such as internal environmental management, green purchasing, and customer environmental performance, concerning better environmental performance. It initiates introducing green innovation as a significant moderator between green practices of supply chain management like internal environmental management, green purchasing, and customer environmental cooperation. As far as empirical implications of the paper are concerned, this is useful in providing sufficient guidance to business management on how to improve the degree of environmental performance by implementing green supply chain management practices in general and three major green supply chain management practices like internal environmental management, green purchasing, and customer environmental cooperation in particular. The study clarifies if internal environmental management practices are implemented efficiently, there is a green procurement of material and resources, and customers cooperate with the business enterprises, the enterprises can show superior environmental performance. Our study also elaborates on the contribution of green innovation in achieving superior performance. In green innovation, the influence of internal environmental management, green purchasing, and customer environmental cooperation on the attainment of environmental performance become more effective.

\section{Conclusion and Limitations}

In short, the study examines that there is a positive association between internal environmental management and environmental performance. The more efficiently and effectively implemented practices of internal environmental management bring improvement in environmental performance. Similarly, the study results prove that green purchasing has a positive impact on the environmental performance of industrial enterprises. The green procurement of material and organizational resources helps to achieve superior environmental performance. Similarly, the study elaborates that customer environmental cooperation is in a positive relationship with enterprises' environmental performance. The more the customer environmental cooperation with business organizations, the superior is the concerned enterprises' environmental performance.

Moreover, the study implies that green innovation is a considerable moderator between internal environmental management and environmental performance as when the business organization takes care of green innovation the implementation of green supply chain management practices can affect the environmental performance in a stronger way. And, the study states that green innovation proves to be a suitable moderator between green purchasing and environmental performance. Besides, the paper concludes that green innovation can be taken as a significant moderator between customer environmental cooperation and environmental performance as the organization's struggle to bring green innovation in their operations, production, and marketing procedures strengthens the effects of customer environmental cooperation on environmental performance. 
The paper has several limitations despite its detailed description of green supply chain management, some of its significant practices like internal environmental management, green purchasing, and customer environmental cooperation and their importance to the achievement of environmental performance. The first limitation in this study to be noted is that this paper addresses only three above mentioned practices of green supply chain management which put considerable impacts on the environmental performance of the business enterprises while are a greater number of dimensions of green supply chain management which have a deep relation with the achievement of superior environmental. But these dimensions of green supply chain management are left by this study unaddressed and are recommended to be addressed by future studies. Moreover, the author has used a single source for the collection of data in support of this study. Due to a single source's usage, the data acquired is limited both in quantity and quality. Thus future academics are recommended to utilize multiple reliable sources to collect data, which guarantees the acquisition of data in sufficient quantity and accurate in quality. Besides, the scope of this study is limited because the data used in support of this study has been acquired just from the industry of Bahrain, and on the other hand, data is collected from a single industry hydrocarbon industry. So, this study lacks generalizability, and thus future scholars are recommended to make their studies generalizable by acquiring data from more than one industry and more than one country in support of their study.

\section{References}

Ahmed, U. (2019). Influencing Youth Involvement in Entrepreneurship: Implications for Policy Makers in the Kingdom of Bahrain. Annals of Contemporary Developments in Management \& HR (ACDMHR), 1(3), 39-52.

Athiyaman, A., \& Magapa, T. (2019). Market Intelligence From The Internet: An Illustration Using The Biomass Heating Industry. International Journal Of Economics And Finance Studies, 11(1), 1-16.

Afonso, A., \& Silva, J. (2019). Efectos de la política monetaria de la zona del euro en los sectores institucionales: el caso de Portugal. Cuadernos de Economía, 42(120).

Auriacombe, C. J., \& Vyas-Doorgapersad, S. (2019). Critical considerations for the role of governments in the interface between good governance and sustainable development in developing countries.

Bernauer, T., Engel, S., Kammerer, D., \& Sejas Nogareda, J. (2007). Explaining green innovation: ten years after Porter's win-win proposition: how to study the effects of regulation on corporate environmental innovation? Politische Vierteljahresschrift, 39, 323-341.

Bonal, J. R., Lorenzo Calvo, A., \& Jiménez Saiz, S. L. (2019). Key Factors on Talent Development of Expertise Basketball Players in China. Revista de psicología del deporte, 28(3), 0009-16.

Galatti, L. R., Marques, R. F., Barros, C. E., Montero Seoane, A., \& Rodrigues Paes, R. (2019). Excellence in Women Basketball: Sport Career Development of World Champions and Olympic Medalists Brazilian Athletes. Revista de psicología del deporte, 28(3), 0017-23.

Carrión-Flores, C. E., \& Innes, R. (2010). Environmental innovation and environmental performance. Journal of Environmental Economics and Management, 59(1), 27-42.

Chiou, T.-Y., Chan, H. K., Lettice, F., \& Chung, S. H. (2011). The influence of greening the suppliers and green innovation on environmental performance and competitive advantage in Taiwan. Transportation Research Part E: Logistics and Transportation Review, 47(6), 822-836.

Cuerva, M. C., Triguero-Cano, Á., \& Córcoles, D. (2014). Drivers of green and non-green innovation: empirical evidence in Low-Tech SMEs. Journal of Cleaner Production, 68, 104-113.

Casas-Rosal, JC, del Rosal, DEC, Caridad, JM, \& Tabales, JMN (2019). Real estate market in Spain: A tool for supply analysis. Cuadernos de Economia: Spanish Journal of Economics and Finance, 42 (120), 207-218.

Chetthamrongchai, P., Jermsittiparsert, K., \& Saengchai, S. (2019). The Mediating Role of Pharmacy Engagement on the Relationship of Perceived Service Quality, Customer Perception, Price Strategy with Pharmacy Customer Devotion. Systematic Reviews in Pharmacy, 10(2), 120-129.

Darwish, S, Abdo, H., .Alshuwaiee, W. (2018) Opportunities, Challenges and Risks of Transition into Renewable Energy: The Case of the Arab Gulf Cooperation Council, International Energy Journal, 18(4), 391-400.

Darwish ,S \& Bunagan, V. (2019) Innovation in Energy Systems: Paradigms in Operation in Business and Development, International Journal of Scientific \& Technology Research, 8(1), 1264-1271.

Diabat, A., \& Govindan, K. (2011). An analysis of the drivers affecting the implementation of green supply chain management. Resources, Conservation and Recycling, 55(6), 659-667.

Dubey, R., Gunasekaran, A., \& Ali, S. S. (2015). Exploring the relationship between leadership, operational practices, institutional pressures and environmental performance: A framework for green supply chain. International Journal of Production Economics, 160, 120-132.

Eltayeb, T., \& Zailani, S. (2014). Going Green through Green Supply Chain Initiatives Toward Environmental Sustainability. Operations and Supply Chain Management: an International Journal, 2(2), 93-110.

Epstein, M. J., Buhovac, A. R., \& Yuthas, K. (2015). Managing social, environmental and financial performance simultaneously. Long Range Planning, 48(1), 35-45.

Farahat, A. (2016). Air pollution in the Arabian Peninsula (Saudi Arabia, the United Arab Emirates, Kuwait, Qatar, Bahrain, and Oman): causes, effects, and aerosol categorization. Arabian Journal of Geosciences, 9(3), 196-214.

González-Benito, J., Lannelongue, G., Ferreira, L. M., \& Gonzalez-Zapatero, C. (2016). The effect of green purchasing on purchasing performance: the moderating role played by long-term relationships and strategic integration. Journal of Business \& Industrial Marketing, 31(2), 312-324. 
Green, K. W., Zelbst, P. J., Meacham, J., \& Bhadauria, V. S. (2012). Green supply chain management practices: impact on performance. Supply Chain Management: An International Journal, 17(3), 290-305.

Galatti, L. R., Marques, R. F., Barros, C. E., Montero Seoane, A., \& Rodrigues Paes, R. (2019). Excellence in Women Basketball: Sport Career Development of World Champions and Olympic Medalists Brazilian Athletes. Revista de psicología del deporte, 28(3), 0017-23.

Hadi, N. R. (2019). 2 Ministry of Pharmacology and Therapeutics , Kufa University of Medicine , Iraq of Health , Karbalaa , Iraq . 3 Al Najaf Cardiac Centre , Kufa University of Medicine, Iraq . 4 School of Life Sciences, College of Science , Health and Engineering, La Trobe University, Bundoora, VIC, Australia 3086 Correspondance : Najah R . Hadi et al : The Impact of Atorvastatin reload in Patients undergoing Percutaneous Coronary Intervention and its Correlation with the Toll-like Receptors. https://doi.org/10.5530/srp.2019.2.10

Isabirye, A., \& Moloi, K. (2019). Addressing Trainees'concerns In A Professional Development Programme For Innovative Teaching And Learning. The International Journal Of Social Sciences And Humanity Studies, 11(1), 1-18.

Ji, P., Ma, X., \& Li, G. (2015). Developing green purchasing relationships for the manufacturing industry: An evolutionary game theory perspective. International Journal of Production Economics, 166, 155-162.

Khayati A., Al-Sayegh J. (2020) The Journey of Bahrain to Economic Diversification. In: Miniaoui H. (eds) Economic Development in the Gulf Cooperation Council Countries. Gulf Studies, vol 1. Springer, Singapore. https://doi.org/10.1007/978-981-15-6058-3 8

Laari, S., Töyli, J., Solakivi, T., \& Ojala, L. (2016). Firm performance and customer-driven green supply chain management. Journal of Cleaner Production, 112, 1960-1970.

Laosirihongthong, T., Adebanjo, D., \& Tan, K. C. (2013). Green supply chain management practices and performance. Industrial Management \& Data Systems, 113(8), 1088-1109.

Large, R. O., \& Thomsen, C. G. (2011). Drivers of green supply management performance: Evidence from Germany. Journal of Purchasing and Supply Management, 17(3), 176-184.

Li, Y. (2014). Environmental innovation practices and performance: moderating effect of resource commitment. Journal of Cleaner Production, 66, 450-458.

Lin, R.-J. (2013). Using fuzzy DEMATEL to evaluate the green supply chain management practices. Journal of Cleaner Production, 40, 32-39.

López-Gamero, M. D., \& Molina-Azorín, J. F. (2016). Environmental management and firm competitiveness: the joint analysis of external and internal elements. Long Range Planning, 49(6), 746-763.

Louër, L. (2013). Sectarianism and coup-proofing strategies in Bahrain. Journal of Strategic Studies, 36(2), $245-260$.

Marelli, A. (2015). The evolving role of environmental management accounting in internal decision-making: a research note. International Journal of Accounting, Auditing and Performance Evaluation, 11(1), 14-47.

Mokoena, B. A., \& Dhurup, M. (2019). Self-Efficacy, Organisational Commitment, Job Satisfaction and Satisfaction With Life Relationships: a Study Among Amateur Sport Coaches in South Africa. The International Journal of Social Sciences and Humanity Studies, 11(1), 19-34.

Muposhi, A. (2019). Emergence Of Green Marketing Capitalism In South Africa: Implications For Green Economy Agenda. International Journal Of Business And Management Studies, 11(1), 1-15.

Mokoena, B. A. (2019). A Comparative Analysis Of Markor And Mktor Scales Of Market Orientation On University Performance Among Universities Of Technology In South Africa. International Journal Of Business And Management Studies, 11(1), 16-38.

Mothibi, L., \& Mncayi, P. (2019). Investigating the key drivers of government debt in South Africa: A post-apartheid analysis. International Journal of eBusiness and eGovernment Studies, 11(1), 16-33.

Moolman, A. M., \& Jacobs, L. (2019). The Financial Effect Of\# Feesmustfall On Individual Taxpayers. International Journal Of Economics And Finance Studies, 11(1), 17-32.

Min, H., \& Galle, W. P. (1997). Green purchasing strategies: trends and implications. International Journal of Purchasing and Materials Management, 33(2), 10-17.

Mustafa E. Yaqoob, Humood A. Naser, E. M. Elkanzi \& Essam M. Janahi (2019) Towards an effective environmental impact assessment (EIA) in the industrial sector of Bahrain, Arabian Gulf, Arab Journal of Basic and Applied Sciences, 26 (1), 113-124, DOI: 10.1080/25765299.2019.1570621

Nakibullah, A. (2018). Economic diversification in Bahrain. Applied Economics and Finance, 5(5), 67-74.

Nataraj, M., Maiya, A. G., Karkada, G., Hande, M., Rodrigues, G. S., Shenoy, R., \& Prasad, S. S. (2019). Application of topical oxygen therapy in healing dynamics of diabetic foot ulcers-a systematic review. The Review of Diabetic Studies, $15,74-82$.

Ninlawan, C., Seksan, P., Tossapol, K., \& Pilada, W. (2010). The implementation of green supply chain management practices in electronics industry. Paper presented at the World Congress on Engineering 2012. July 4-6, 2012. London, UK.

Ogalo, H. S. (2020). Strategic Management of HRM Practices and Innovation Performance in the High Tech Fiberglass Sector in Bahrain: Mediating Role of Organizational Innovation. Annals of Contemporary Developments in Management \& HR (ACDMHR), 2(3), 43-55.

Ozgen, K. (2019). Problem-Posing Skills for Mathematical Literacy: The Sample of Teachers and Pre-Service Teachers. Eurasian Journal of Educational Research, 84, 177-212. 
Phankhong, T., Bakar, L. J. A., \& Poespowidjojo, D. A. L. (2020). Examining the Mediating Role of Innovativeness on the Relationship between Innovation Strategy, Atmosphere, Culture and Performance of Hotel Industry in Thailand: A Pilot Study. Annals of Contemporary Developments in Management \& HR (ACDMHR), 2(2), 29-39.

Paillé, P., Chen, Y., Boiral, O., \& Jin, J. (2014). The impact of human resource management on environmental performance: An employee-level study. Journal of Business Ethics, 121(3), 451-466.

Polat, S., Guncavdi, G., \& Arslan, Y. (2019). The Impacts of a University's Organizational Reputation and Organizational Attraction on Students' Intention to Pursue. Eurasian Journal of Educational Research, 84, 213-236.

Piltan, F., Mansoorzadeh, M., Akbari, M., Zare, S., \& ShahryarZadeh, F. (2013). Management of Environmental Pollution by Intelligent Control of Fuel in an Internal Combustion Engine. Global Journal of Biodiversity Science And Management, 3(1), 145-155.

Papanas, N., Pafili, K., Demetriou, M., Chatzikosma, G., Papachristou, S., \& Papazoglou, D. (2019). Automated Measurement of Sural Nerve Conduction is a Useful Screening Tool for Peripheral Neuropathy in Type 1 Diabetes Mellitus. The Review of Diabetic Studies, 15(1).

Qi, G., Shen, L. Y., Zeng, S., \& Jorge, O. J. (2010). The drivers for contractors' green innovation: an industry perspective. Journal of Cleaner Production, 18(14), 1358-1365.

Sarkis, J. (2012). A boundaries and flows perspective of green supply chain management. Supply Chain Management: An International Journal, 17(2), 201-216.

Sarkis, J., Zhu, Q., \& Lai, K.-h. (2011). An organizational theoretic review of green supply chain management literature. International Journal of Production Economics, 130(1), 1-15.

Sarstedt, M., \& Cheah, J.-H. (2019). Partial least squares structural equation modeling using SmartPLS: a software review. Journal of Marketing Analytics, 7(3), 196-202.

Schiederig, T., Tietze, F., \& Herstatt, C. (2012). Green innovation in technology and innovation management-an exploratory literature review. R\&d Management, 42(2), 180-192.

Seman, N. A. A., Govindan, K., Mardani, A., Zakuan, N., Saman, M. Z. M., Hooker, R. E., \& Ozkul, S. (2019). The mediating effect of green innovation on the relationship between green supply chain management and environmental performance. Journal of Cleaner Production, 229, 115-127.

Soofi, K., \& Pai, S. (2018). The Use of Autonomous Marine Vehicles by the Hydrocarbon Industry: A Proof of Concept Mission. Marine Technology Society Journal, 52(6), 32-38.

Sarkın, D. B. Ş., \& Gülleroğlu, H. D. (2019). Anxiety in Prospective Teachers: Determining the Cut-off Score with Different Methods in Multi-Scoring Scales. Educational Sciences: Theory \& Practice, 19(1).

Tekir, S., \& Akar, H. (2019). The Current State of Instructional Materials Education: Aligning Policy, Standards, and Teacher Education Curriculum. Educational Sciences: Theory \& Practice, 19(1).

Theyel, G. (2006). Customer and supplier relations for environmental performance Greening the supply chain (pp. 139149): Springer.

Tseng, M.-L., Islam, M. S., Karia, N., Fauzi, F. A., \& Afrin, S. (2019). A literature review on green supply chain management: Trends and future challenges. Resources, Conservation and Recycling, 141, 145-162.

Walls, J. L., Berrone, P., \& Phan, P. H. (2012). Corporate governance and environmental performance: Is there really a link? Strategic Management Journal, 33(8), 885-913.

Weng, H.-H. R., Chen, J.-S., \& Chen, P.-C. (2015). Effects of green innovation on environmental and corporate performance: A stakeholder perspective. Sustainability, 7(5), 4997-5026.

Yang, M. G. M., Hong, P., \& Modi, S. B. (2011). Impact of lean manufacturing and environmental management on business performance: An empirical study of manufacturing firms. International Journal of Production Economics, 129(2), 251261.

Yen, Y.-X., \& Yen, S.-Y. (2012). Top-management's role in adopting green purchasing standards in high-tech industrial firms. Journal of Business Research, 65(7), 951-959.

Zeng, S., Meng, X., Zeng, R., Tam, C. M., Tam, V. W., \& Jin, T. (2011). How environmental management driving forces affect environmental and economic performance of SMEs: a study in the Northern China district. Journal of Cleaner Production, 19(13), 1426-1437.

Zhu, Q., Geng, Y., \& Lai, K.-h. (2010). Circular economy practices among Chinese manufacturers varying in environmental-oriented supply chain cooperation and the performance implications. Journal of Environmental Management, 91(6), 1324-1331. 
(C) 2021 by the authors; licensee Growing Science, Canada. This is an open access article distributed under the terms and conditions of the Creative Commons Attribution (CC-BY) license (http://creativecommons.org/licenses/by/4.0/). 